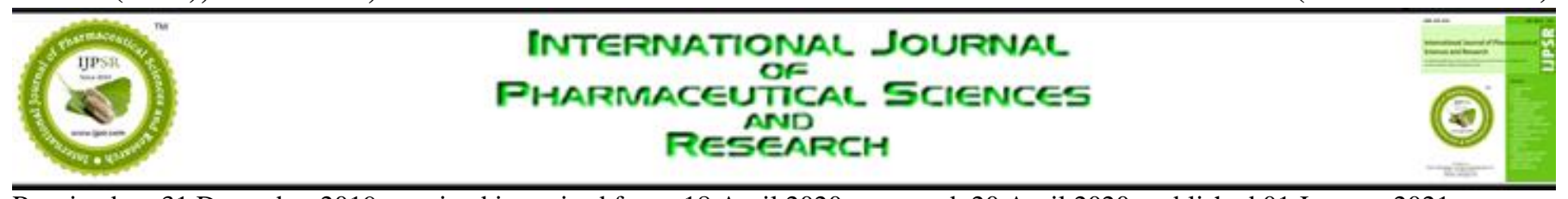

Received on 31 December 2019; received in revised form, 18 April 2020; accepted, 20 April 2020; published 01 January 2021

\title{
DEVELOPMENT AND VALIDATION OF RP-HPLC METHOD FOR THE SIMULTANEOUS ESTIMATION OF DAPAGLIFLOZIN AND SAXAGLIPTIN IN BULK AND PHARMACEUTICAL DOSAGE FORMS
}

Narender Boggula * and P. Shanmuga Pandiyan

Faculty of Pharmaceutical Sciences, Mewar University, Mewar Chittorgarh - 312901, Rajasthan, India.

\section{Keywords:}

Dapagliflozin, Saxagliptin, Validation, Linearity, Recovery, ICH guide

\section{Correspondence to Author:}

Mr. Narender Boggula

Research Scholar,

Faculty of Pharmaceutical Sciences, Mewar University, Mewar Chittorgarh - 312901, Rajasthan, India.

E-mail: narender.b987@gmail.com

\begin{abstract}
An analytical method consists of a detailed, stepwise list of instructions to be followed in the qualitative, quantitative, or structural analysis of a sample for one or more analytes and using a specified technique. A novel, simple, precise, sensitive, and reproducible RP-HPLC method for the simultaneous estimation of Dapagliflozin and Saxagliptin in bulk and pharmaceutical formulation was developed and validated. The separation was carried out on Symmetry $C_{8}(4.6 \times 150 \mathrm{~mm}, 3.5 \mu \mathrm{m}$, Make: XTerra) column with buffer: acetonitrile in the ratio of $70: 30 \% \mathrm{v} / \mathrm{v}(\mathrm{pH} 3)$ as the mobile phase at the flow rate of $1 \mathrm{ml} / \mathrm{min}$. The eluent detection was carried out using a UVVisible detector at $221 \mathrm{~nm}$. The retention time of Dapagliflozin and Saxagliptin was $2.83 \mathrm{~min}$ and $4.35 \mathrm{~min}$, respectively. Linearity was observed Dapagliflozin and Saxagliptin in the concentration range of $25-125 \mu \mathrm{g} / \mathrm{ml}$ and $12.5-62.5 \mu \mathrm{g} / \mathrm{ml}$, respectively. The \% mean recovery of Dapagliflozin and Saxagliptin was found to be 99.90 and 99.99 , respectively. The present study demonstrates the applicability of chromatographic method to develop a new, sensitive, single RPHPLC method for the simultaneous quantitative determination of Dapagliflozin and Saxagliptin in a fixed pharmaceutical dosage form. Hence, this method can be conveniently adopted for routine analysis in quality control laboratories.
\end{abstract}

INTRODUCTION: Analytical chemistry is a branch of chemistry that deals with the identification of compounds and mixtures (qualitative analysis) or the determination of the proportions of the constituents (quantitative analysis). In the modern pharmaceutical industry, high-performance liquid chromatography (HPLC) is the major and integral analytical tool applied in all stages of drug discovery, development, and production. The development of new chemical entities (NCEs) is comprised of two major activities: drug discovery and drug development ${ }^{1,2}$.

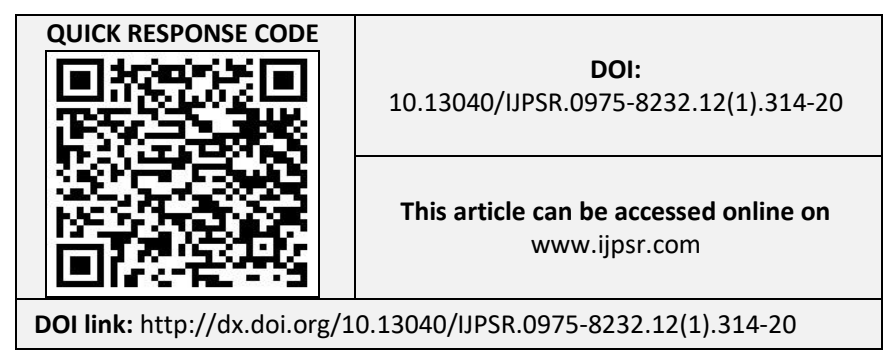

It is one of the significant roles for the physician in the treatment of patients with type- 2 diabetes. Type-2 diabetes is known as diabetes mellitus. It is a long term metabolic disorder that is characterized by high blood sugar and insulin resistance ${ }^{3,4}$.

To overcome these problems, an oral combination therapy of Dapagliflozin and Saxagliptin was introduced for the treatment of Type-2 diabetes. Dapagliflozin is a drug of the gliflozin class which specifically inhibits subtype 2 of the sodiumglucose transport proteins (SGLT2) which are responsible for at least $90 \%$ of the glucose reabsorption in the kidney. Saxagliptin is an oral hypoglycemic drug which inhibits the dipeptidyl peptidase-4 (DPP-4) enzyme and reduces the blood glucose level ${ }^{4,5}$. Clinical trials for Dapagliflozin and Saxagliptin oral combination therapy indicate that it is safety, efficacy, rapid and intensive control over high blood glucose level. 
So, the combination of Dapagliflozin and Saxagliptin is clinically approved for the treatment of Type-2 diabetes Fig. 1 and Fig. $2{ }^{5,6}$. The techniques commonly used are titration, precipitation, spectroscopy, chromatography, etc. Highperformance liquid chromatography (HPLC) is the fastest-growing analytical technique for the analysis of drugs ${ }^{1}$. Its simplicity, high specificity,

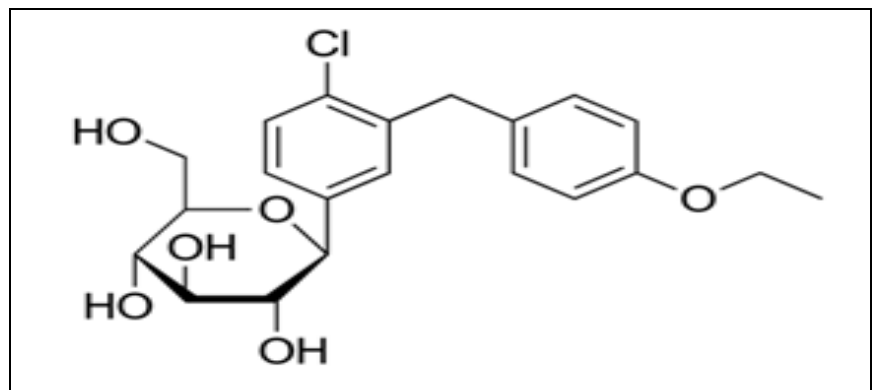

FIG. 1: CHEMICAL STRUCTURE OF DAPAGLIFLOZIN

MATERIALS AND METHODS: An isocratic RP-HPLC method was performed on a Waters 515 PDA 2998 Detector HPLC system equipped with empowering software for processing and data collecting. Symmetry $\mathrm{C}_{8}(4.6 \times 150 \mathrm{~mm}, 3.5 \mu \mathrm{m}$, Make: XTerra) column is used as a stationary phase. An ultrasonic bath sonicator (Frontline FS 4, Mumbai, India), semi-micro analytical balance (India), and Whatman filter paper no. 41 is used in the study.

Dapagliflozin and Saxagliptin were procured from Manus Aktteva Biopharma Ltd., India. Acetonitrile of HPLC grade was procured from Merck Specialities Private Limited, Mumbai, India. Water and orthophosphoric acid of HPLC grade was obtained from Rankem Ltd., India. HPLC grade of potassium dihydrogen orthophosphate was procured from Rankem Ltd., India. Qtern® tablets were procured from AstraZeneca Pharmaceuticals.

The separation was carried out on Symmetry C8 $(4.6 \times 150 \mathrm{~mm}, 3.5 \mu \mathrm{m}$, Make: XTerra) column with buffer: acetonitrile in the ratio of $70: 30 \% \mathrm{v} / \mathrm{v}$ $(\mathrm{pH} 3)$ as the mobile phase at the flow rate of $1 \mathrm{ml} / \mathrm{min}$. The eluent detection was carried out using a UV-Visible detector at $221 \mathrm{~nm}$. The injection volume was $20 \mu \mathrm{l}$, and the analysis was performed at ambient temperature.

Preparation of Dapagliflozin and Saxagliptin Mixed Standard Drug Stock Solutions: ${ }^{8}$ The mixed standard drug stock solutions of and wide range of sensitivity make it ideal for the analysis of many drugs in both dosage forms and biological fluids ${ }^{7}$. For this instance, an attempt has been made to develop and validate a novel RPHPLC method for the simultaneous estimation of Dapagliflozin and Saxagliptin in the combined tablet dosage form.

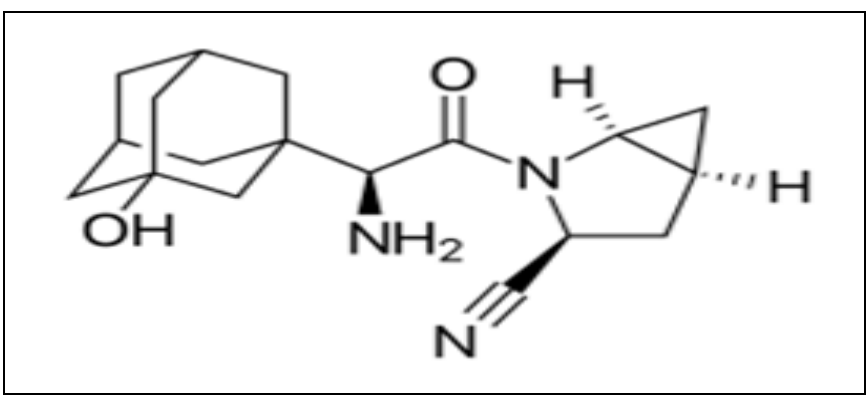

FIG. 2: CHEMICAL STRUCTURE OF SAXAGLIPTIN

Dapagliflozin and Saxagliptin were prepared by dissolving $10 \mathrm{mg}$ of Dapagliflozin and $5 \mathrm{mg}$ of Saxagliptin in $10 \mathrm{~mL}$ of the mobile phase into a 10 $\mathrm{mL}$ of volumetric flask and then sonicated to dissolve it completely to get a concentration of $1000 \mu \mathrm{g} / \mathrm{mL}$ of Dapagliflozin and $500 \mu \mathrm{g} / \mathrm{mL}$ of Saxagliptin.

Preparation of Sample Solution: ${ }^{9}$ Sample solution was prepared from Qtern® tablets. Twenty tablets of Qtern ${ }^{\circledR}$ were taken and weighed individually, and the average weight of twenty tablets was calculated. From this calculation, the weight of each tablet is determined. Each tablet of Qtern ${ }^{\circledR}$ contains $10 \mathrm{mg}$ of Dapagliflozin and $5 \mathrm{mg}$ of Saxagliptin. After weighing, twenty tablets of Qtern ${ }^{\circledR}$ were crushed and mixed in a mortar and pestle to produce a powder. An accurately weighed quantity of powder equivalent to $10 \mathrm{mg}$ of Dapagliflozin and $5 \mathrm{mg}$ of Saxagliptin was transferred into a clean, and dry $10 \mathrm{~mL}$ volumetric flask and then mobile phase was added and sonicated to dissolve it completely and filtered through $0.45 \mu \mathrm{m}$ nylon membrane filter and volume was made up to the mark with the same mobile phase to get the concentration of 1000 $\mu \mathrm{g} / \mathrm{mL}$ of Dapagliflozin and $500 \mu \mathrm{g} / \mathrm{mL}$ of Saxagliptin.

An aliquot of $0.5 \mathrm{~mL}$ was pipette out from the above solution and then transferred into a $10 \mathrm{ml}$ of volumetric flask and diluted up to mark with the mobile phase to get the concentration of $50 \mu \mathrm{g} / \mathrm{mL}$ 
of Dapagliflozin and $25 \mu \mathrm{g} / \mathrm{mL}$ of Saxagliptin solution.

Validation: ${ }^{10}$ The method was validated for linearity, precision, specificity, accuracy, and robustness as per the ICH guidelines. Linearity was observed Dapagliflozin and Saxagliptin in the concentration range of $25-125 \mu \mathrm{g} / \mathrm{ml}$ and 12.5-62.5 $\mu \mathrm{g} / \mathrm{ml}$, respectively. The $\%$ mean recovery of Dapagliflozin and Saxagliptin was found to be 99.90 and 99.99 , respectively.

Accuracy was determined at three different levels of $50 \%, 100 \%$, and $150 \%$ of the target concentration of the active ingredient by adding a known amount of each standard to previously analyzed tablet samples. Precision was studied to determine intraday variation by performing six replicate assays of the tablet sample. The \% RSD was calculated for intraday precision. Robustness of the method was carried out by deliberately changing the mobile phase composition by altering the proportion of the organic phase by $\pm 10 \%$ and flow rate by $\pm 0.1 \mathrm{~mL}$. Specificity was by using a placebo of commonly used tablet excipients ${ }^{11-13}$.

RESULTS AND DISCUSSION: The present RPHPLC method for the simultaneous estimation of Dapagliflozin and Saxagliptin in bulk and pharmaceutical dosage forms was established and validated as per ICH guidelines. This method was intended for rapid and accurate estimation of Dapagliflozin and Saxagliptin in bulk and pharmaceutical dosage forms. Good separation of the chromatographic peaks was observed, and no interfering peaks are found. A number of commercially available HPLC columns and various mobile phases were used for the development of the RP-HPLC method for the simultaneous estimation of Dapagliflozin and Saxagliptin in bulk and pharmaceutical dosage forms Fig. 5, 6 and 7. The best response was obtained with Symmetry $\mathrm{C}_{8}$ $(4.6 \times 150 \mathrm{~mm}, 3.5 \mu \mathrm{m}$ particle size $)$; Waters 515
PDA 2998 Detector HPLC system and mobile phase contained a mixture of Potassium dihydrogen orthophosphate $(\mathrm{pH}$ adjusted to 3 with orthophosphoric acid) and Acetonitrile (30:70, v/v) was delivered at a flow rate of $1 \mathrm{~mL} / \mathrm{min}$. Quantitation was attained with a PDA detector at $221 \mathrm{~nm}$ depends on peak area. The retention time of Dapagliflozin and Saxagliptin was $2.831 \mathrm{~min}$ and $4.357 \mathrm{~min}$ with a resolution of 4.718 .

Linearity was established for Dapagliflozin and Saxagliptin in the range of $25-125 \mu \mathrm{g} / \mathrm{mL}$ for Dapagliflozin, and 12.5-62.5 $\mu \mathrm{g} / \mathrm{mL}$ for Saxagliptin with correlation coefficients $(r=0.999)$ and the percentage recoveries were between $99.82 \%$ $100.01 \%$ for Dapagliflozin and $99.95 \%-100.04 \%$ for Saxagliptin, respectively Table 2, Fig. 3 and 4.

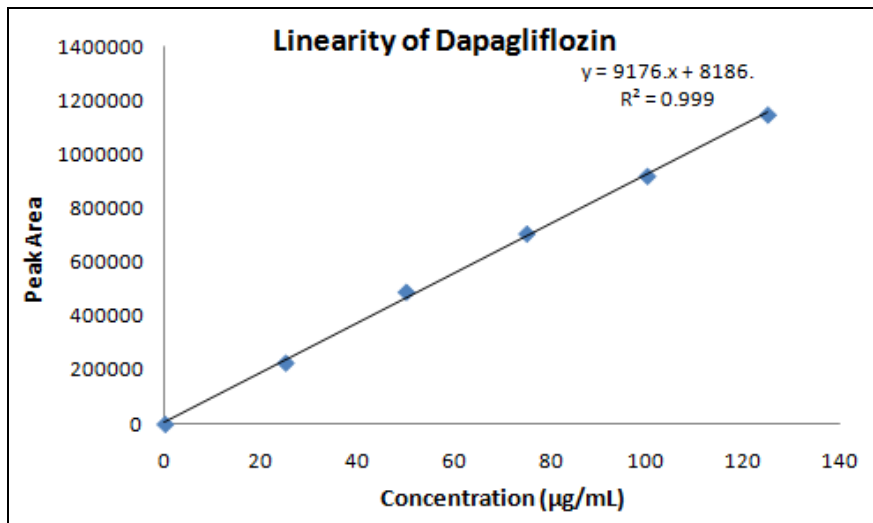

FIG. 3: LINEARITY GRAPH OF DAPAGLIFLOZIN

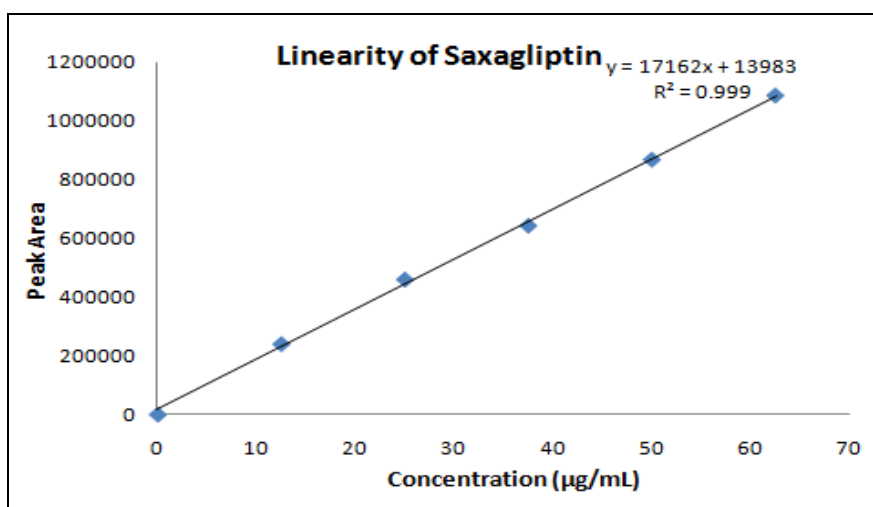

FIG. 4: LINEARITY GRAPH OF SAXAGLIPTIN

\section{TABLE 1: SYSTEM SUITABILITY PARAMETERS OF DAPAGLIFLOZIN AND SAXAGLIPTIN}

\begin{tabular}{|c|c|c|c|}
\hline Parameters & Dapagliflozin & Saxagliptin & Acceptance limits \\
\hline Retention time (min) & 2.831 & 4.357 & ----- \\
\hline Theoretical plates $(\mathrm{N})$ & 2332 & 3218 & Not less than 2000 \\
\hline Asymmetry factor & 1.02 & 1.04 & Not more than 2 \\
\hline Resolution & & 4.718 & More than 2 \\
\hline Linearity range $(\mu \mathrm{g} / \mathrm{mL})$ & $25-125$ & $12.5-62.5$ & ----- \\
\hline Limit of detection (LOD) $(\mu \mathrm{g} / \mathrm{mL})$ & 0.23 & 0.08 & ----- \\
\hline Limit of quantification (LOQ) $(\mu \mathrm{g} / \mathrm{mL})$ & 0.68 & 0.24 & ----- \\
\hline
\end{tabular}


TABLE 2: LINEARITY OF DAPAGLIFLOZIN AND SAXAGLIPTIN

\begin{tabular}{cccc}
\hline $\begin{array}{c}\text { Concentration of } \\
\text { Dapagliflozin } \\
(\boldsymbol{\mu g} / \mathbf{m L})\end{array}$ & $\begin{array}{c}\text { Peak } \\
\text { Area }\end{array}$ & $\begin{array}{c}\text { Concentration } \\
\text { of Saxagliptin } \\
(\boldsymbol{\mu g} / \mathbf{m L})\end{array}$ & $\begin{array}{c}\text { Peak } \\
\text { Area }\end{array}$ \\
\hline 25 & 227288 & 12.5 & 240522 \\
50 & 490023 & 25 & 460387 \\
75 & 706102 & 37.5 & 643827 \\
100 & 919842 & 50 & 869362 \\
125 & 1147218 & 62.5 & 1087692 \\
\hline
\end{tabular}

TABLE 3: OPTICAL AND REGRESSION PARAMETERS OF DAPAGLIFLOZIN AND SAXAGLIPTIN

\begin{tabular}{ccc}
\hline $\begin{array}{c}\text { Optical and regression } \\
\text { parameters }\end{array}$ & Dapagliflozin & Saxagliptin \\
\hline $\begin{array}{c}\text { Detection wavelength }(\mathrm{nm}) \\
\text { Linearity range }(\mu \mathrm{g} / \mathrm{mL})\end{array}$ & $25-125$ & 221 \\
Regression Equation & $9176 \mathrm{x}+8186$ & $17162 \mathrm{x}+13983$ \\
$(\mathrm{y}=\mathrm{mx}+\mathrm{C})$ & & \\
Slope $(\mathrm{m})$ & 9176 & 17162 \\
Intercept $(\mathrm{C})$ & 8186 & 13983 \\
Correlation coefficient $(\mathrm{r})$ & 0.999 & 0.999 \\
Limit of detection $(\mu \mathrm{g} / \mathrm{mL})$ & 0.23 & 0.08 \\
Limit of quantification & 0.68 & 0.24 \\
$(\mu \mathrm{g} / \mathrm{mL})$ & &
\end{tabular}

The RSD \% values of accuracy for Dapagliflozin and Saxagliptin were found to be $<2 \%$, which indicate the accuracy of the proposed method Table 4 and 5. The RSD \% values of method precision were found to be $0.11 \%$ for Dapagliflozin and $0.08 \%$ for Saxagliptin, respectively, and for the system, precision was found to be $0.19 \%$ for Dapagliflozin and $0.45 \%$ for Saxagliptin,

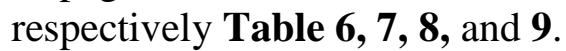

The RSD \% values of reproducibility were found to be $0.024 \%$ for Dapagliflozin and $0.02 \%$ for Saxagliptin, respectively Table $\mathbf{1 0}$ and $\mathbf{1 1}$ reveal that the proposed method is precise. LOD values were found to be $0.23 \mu \mathrm{g} / \mathrm{mL}$ for Dapagliflozin and $0.08 \mu \mathrm{g} / \mathrm{mL}$ for Saxagliptin and LOQ values were found to be $0.68 \mu \mathrm{g} / \mathrm{mL}$ for Dapagliflozin and 0.24 $\mu \mathrm{g} / \mathrm{mL}$ for Saxagliptin Table 2. The RSD \% values of robustness studies were found to be $<2 \%$, which indicate the robustness of the proposed method Table 12 and 13. These reports show that the proposed method was accurate and precise for the simultaneous determination of Dapagliflozin and Saxagliptin in bulk and pharmaceutical combined dosage forms.

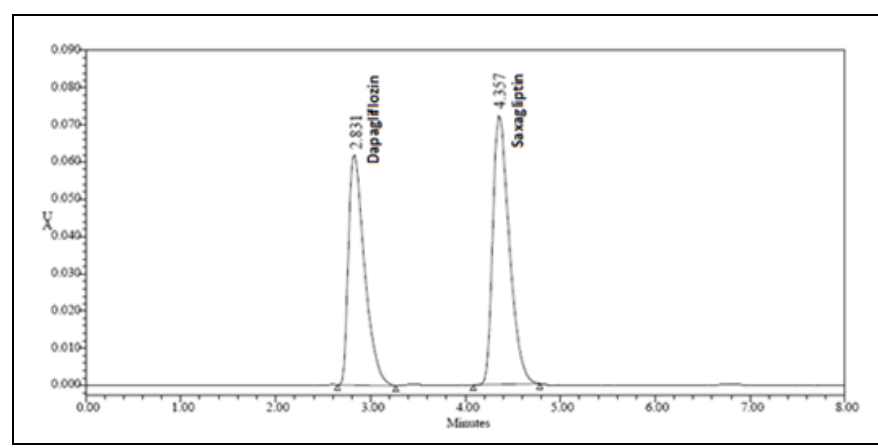

FIG. 5: REPRESENTATIVE CHROMATOGRAM OF STANDARD SOLUTION OF DAPAGLIFLOZIN AND SAXAGLIPTIN

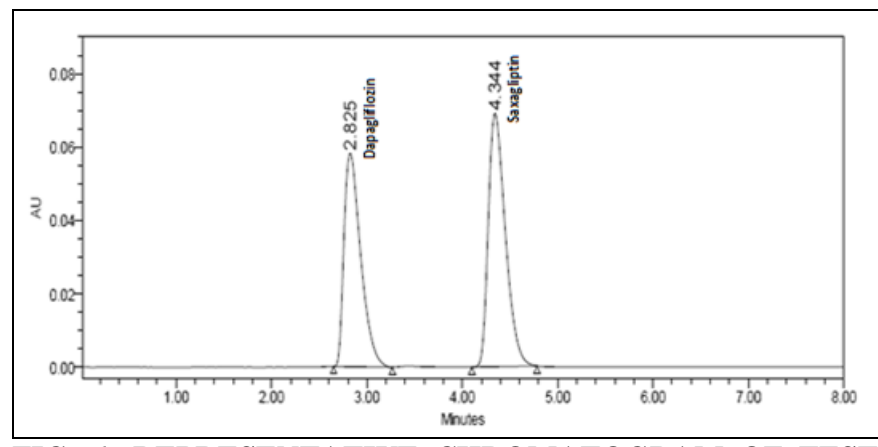

FIG. 6: REPRESENTATIVE CHROMATOGRAM OF TEST SOLUTION OF DAPAGLIFLOZIN AND SAXAGLIPTIN

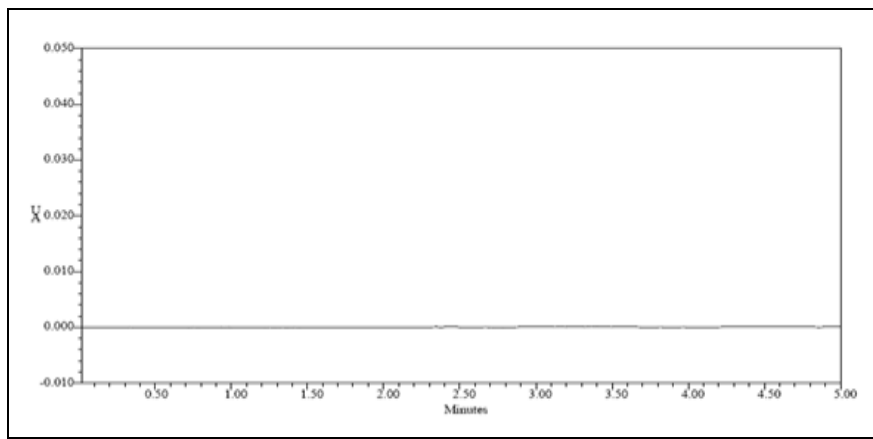

FIG. 7: REPRESENTATIVE CHROMATOGRAM OF BLANK

TABLE 4: RESULTS OF ACCURACY STUDIES OF DAPAGLIFLOZIN

\begin{tabular}{cccccc}
\hline $\begin{array}{c}\text { Concentration } \\
\text { Level in \% }\end{array}$ & $\begin{array}{c}\text { Amount added } \\
(\boldsymbol{\mu g} / \mathbf{m L})\end{array}$ & $\begin{array}{c}\text { Amount recovered } \\
(\boldsymbol{\mu g} / \mathbf{m L})\end{array}$ & \% Recovery & $\begin{array}{c}\text { \% Mean } \\
\text { Recovery }\end{array}$ & RSD \% \\
\hline $\mathrm{S}_{1}: 50 \%$ & 25 & 24.96 & 99.84 & 99.89 & 0.24 \\
$\mathrm{~S}_{2}: 50 \%$ & 25 & 24.92 & 99.68 & & \\
$\mathrm{~S}_{3}: 50 \%$ & 25 & 25.04 & 100.16 & & \\
$\mathrm{~S}_{4}: 100 \%$ & 50 & 49.94 & 99.88 & 99.82 & \\
$\mathrm{~S}_{5}: 100 \%$ & 50 & 49.81 & 99.62 & & \\
$\mathrm{~S}_{6}: 100 \%$ & 50 & 49.98 & 99.96 & & \\
$\mathrm{~S}_{7}: 150 \%$ & 75 & 75.01 & 100.01 & 100.01 & \\
$\mathrm{~S}_{8}: 150 \%$ & 75 & 75.03 & 100.04 & & \\
$\mathrm{~S}_{9}: 150 \%$ & 75 & 74.98 & 99.97 & & \\
\hline
\end{tabular}


TABLE 5: RESULTS OF ACCURACY STUDIES OF SAXAGLIPTIN

\begin{tabular}{cccccc}
\hline $\begin{array}{c}\text { Concentration } \\
\text { Level in \% }\end{array}$ & $\begin{array}{c}\text { Amount added } \\
(\boldsymbol{\mu g} / \mathbf{m L})\end{array}$ & $\begin{array}{c}\text { Amount recovered } \\
(\boldsymbol{\mu g} / \mathbf{m L})\end{array}$ & \% Recovery & $\begin{array}{c}\text { \% Mean } \\
\text { Recovery }\end{array}$ & RSD \% \\
\hline $\mathrm{S}_{1}: 50 \%$ & 12.5 & 12.48 & 99.84 & 99.95 & 0.12 \\
$\mathrm{~S}_{2}: 50 \%$ & 12.5 & 12.49 & 99.92 & & \\
$\mathrm{~S}_{3}: 50 \%$ & 12.5 & 12.51 & 100.08 & & \\
$\mathrm{~S}_{4}: 100 \%$ & 25 & 25.02 & 100.08 & 100.04 & 0.14 \\
$\mathrm{~S}_{5}: 100 \%$ & 25 & 24.97 & 99.88 & & \\
$\mathrm{~S}_{6}: 100 \%$ & 25 & 25.04 & 100.16 & & 0.04 \\
$\mathrm{~S}_{7}: 150 \%$ & 37.5 & 37.48 & 99.95 & 9.98 & \\
$\mathrm{~S}_{8}: 150 \%$ & 37.5 & 37.51 & 100.03 & & \\
$\mathrm{~S}_{9}: 150 \%$ & 37.5 & 37.49 & 99.97 & & \\
\hline
\end{tabular}

TABLE 6: METHOD PRECISION OF DAPAGLIFLOZIN

\begin{tabular}{cccc}
\hline Injection no. & $\mathbf{9 9 . 9 5}$ & $\mathbf{0 . 1 2}$ & Assay \% \\
\hline 1 & & & 99.88 \\
2 & & 99.83 \\
3 & 100.04 & 0.14 & 99.78 \\
4 & & & 100.02 \\
5 & & 99.94 \\
6 & 99.98 & 0.04 & 100.07 \\
& Average & & \\
& SD & & \\
& RSD \% & & 0.11 \\
\hline
\end{tabular}

TABLE 7: METHOD PRECISION OF SAXAGLIPTIN

\begin{tabular}{cccc}
\hline $\begin{array}{c}\text { Injection } \\
\text { no. }\end{array}$ & $\begin{array}{c}\text { Name of the } \\
\text { drug }\end{array}$ & $\begin{array}{c}\text { Concentration } \\
(\boldsymbol{\mu g} / \mathbf{m L})\end{array}$ & Assay \% \\
\hline 1 & Saxagliptin & 25 & 99.89 \\
2 & Saxagliptin & 25 & 100.03 \\
3 & Saxagliptin & 25 & 99.86 \\
4 & Saxagliptin & 25 & 99.97 \\
5 & Saxagliptin & 25 & 99.89 \\
6 & Saxagliptin & 25 & 100.03 \\
& Average & & 99.95 \\
& SD & & 0.075299 \\
& RSD \% & 0.08 \\
\hline
\end{tabular}

TABLE 8: SYSTEM PRECISION OF DAPAGLIFLOZIN

\begin{tabular}{cccc}
$\begin{array}{c}\text { Injection } \\
\text { no. }\end{array}$ & $\begin{array}{c}\text { Name of the } \\
\text { drug }\end{array}$ & $\begin{array}{c}\text { Concentration } \\
(\boldsymbol{\mu g} / \mathbf{m L})\end{array}$ & Assay \% \\
\hline 1 & Dapagliflozin & 50 & 491920 \\
2 & Dapagliflozin & 50 & 492188 \\
3 & Dapagliflozin & 50 & 490332 \\
4 & Dapagliflozin & 50 & 490228 \\
5 & Dapagliflozin & 50 & 491988 \\
6 & Dapagliflozin & 50 & 490389 \\
& Average & & 491174 \\
& SD & & 945.2421 \\
& RSD \% & & 0.19 \\
\hline
\end{tabular}

TABLE 9: SYSTEM PRECISION OF SAXAGLIPTIN

\begin{tabular}{cccc}
\hline $\begin{array}{c}\text { Injection } \\
\text { no. }\end{array}$ & $\begin{array}{c}\text { Name of the } \\
\text { drug }\end{array}$ & $\begin{array}{c}\text { Concentration } \\
(\boldsymbol{\mu g} / \mathbf{m L})\end{array}$ & Assay \% \\
\hline 1 & Saxagliptin & 25 & 491920 \\
2 & Saxagliptin & 25 & 492188 \\
3 & Saxagliptin & 25 & 490332 \\
4 & Saxagliptin & 25 & 490228 \\
5 & Saxagliptin & 25 & 491988 \\
6 & Saxagliptin & 25 & 490389 \\
& Average & & 463183 \\
& SD & & 2095.138 \\
& RSD \% & & 0.45 \\
\hline
\end{tabular}

TABLE 10: RUGGEDNESS AND REPRODUCIBILITY OF DAPAGLIFLOZIN

\begin{tabular}{|c|c|c|c|c|c|c|c|c|}
\hline \multicolumn{5}{|c|}{$\begin{array}{c}\text { Laboratory-1 (Assay \%)-HPLC-1 } \\
\end{array}$} & \multicolumn{4}{|c|}{ Laboratory-2 (Assay \%)-HPLC-2 } \\
\hline \multirow{2}{*}{$\begin{array}{c}\text { Concentration } \\
(\mu \mathrm{g} / \mathrm{mL})\end{array}$} & \multicolumn{2}{|c|}{ Analyst-1 } & \multicolumn{2}{|c|}{ Analyst-2 } & \multicolumn{2}{|c|}{ Analyst-1 } & \multicolumn{2}{|c|}{ Analyst-2 } \\
\hline & Day-1 & Day-2 & Day-1 & Day-2 & Day-1 & Day-2 & Day-1 & Day-2 \\
\hline 50 & 100.02 & 99.89 & 99.87 & 99.92 & 100.03 & 99.81 & 99.87 & 100.08 \\
\hline 50 & 99.99 & 99.97 & 99.99 & 99.97 & 99.94 & 99.93 & 99.98 & 99.97 \\
\hline 50 & 99.83 & 99.93 & 99.96 & 100.03 & 99.77 & 99.96 & 100.02 & 99.62 \\
\hline 50 & 100.01 & 99.96 & 99.92 & 99.98 & 99.98 & 99.89 & 99.94 & 99.69 \\
\hline 50 & 99.97 & 99.99 & 100.01 & 100.02 & 99.95 & 100.02 & 99.68 & 99.63 \\
\hline 50 & 100.04 & 100.01 & 99.94 & 100.01 & 100.14 & 99.99 & 99.94 & 100.09 \\
\hline Average & 99.98 & 99.96 & 99.95 & 99.99 & 99.97 & 99.93 & 99.91 & 99.85 \\
\hline SD & 0.08 & 0.04 & 0.05 & 0.04 & 0.12 & 0.08 & 0.12 & 0.22 \\
\hline $\mathrm{RSD} \%$ & 0.08 & 0.04 & 0.05 & 0.04 & 0.12 & 0.08 & 0.12 & 0.22 \\
\hline \multicolumn{9}{|c|}{ Intermediate precision within-laboratories variations $(n=24)$} \\
\hline \multicolumn{5}{|c|}{ Laboratory-1 (Assay \%)-HPLC-1 } & \multicolumn{4}{|c|}{ Laboratory-2 (Assay \%)-HPLC-2 } \\
\hline Average & \multicolumn{4}{|c|}{99.97} & \multicolumn{4}{|c|}{99.91} \\
\hline $\mathrm{SD}$ & \multicolumn{4}{|c|}{0.02} & \multicolumn{4}{|c|}{0.05} \\
\hline RSD \% & \multicolumn{4}{|c|}{0.02} & \multicolumn{4}{|c|}{0.05} \\
\hline \multicolumn{9}{|c|}{ Reproducibility between laboratories $(n=48)($ Assay \%) } \\
\hline Average & \multicolumn{8}{|c|}{99.94} \\
\hline SD & \multicolumn{8}{|c|}{0.024} \\
\hline $\mathrm{RSD} \%$ & \multicolumn{8}{|c|}{0.024} \\
\hline
\end{tabular}


TABLE 11: RUGGEDNESS AND REPRODUCIBILITY OF SAXAGLIPTIN

\begin{tabular}{|c|c|c|c|c|c|c|c|c|}
\hline \multicolumn{5}{|c|}{$\begin{array}{c}\text { Laboratory-1 (Assay \%)-HPLC-1 } \\
\end{array}$} & \multicolumn{4}{|c|}{ Laboratory-2 (Assay \%)-HPLC-2 } \\
\hline \multirow{2}{*}{$\begin{array}{c}\text { Concentration } \\
(\mu \mathrm{g} / \mathrm{mL})\end{array}$} & \multicolumn{2}{|c|}{ Analyst-1 } & \multicolumn{2}{|c|}{ Analyst-2 } & \multicolumn{2}{|c|}{ Analyst-1 } & \multicolumn{2}{|c|}{ Analyst-2 } \\
\hline & Day-1 & Day-2 & Day-1 & Day-2 & Day-1 & Day-2 & Day-1 & Day-2 \\
\hline 25 & 99.44 & 99.89 & 99.98 & 100.03 & 100.03 & 99.67 & 99.34 & 100.03 \\
\hline 25 & 99.89 & 99.97 & 99.97 & 100.04 & 99.89 & 99.92 & 99.89 & 99.81 \\
\hline 25 & 99.56 & 99.88 & 99.93 & 99.98 & 100.02 & 99.69 & 99.92 & 99.79 \\
\hline 25 & 100.07 & 99.79 & 99.94 & 99.56 & 99.89 & 99.93 & 100.05 & 100.07 \\
\hline 25 & 99.95 & 100.11 & 99.78 & 100.02 & 99.74 & 100.01 & 100.09 & 99.87 \\
\hline 25 & 99.93 & 100.04 & 99.98 & 99.87 & 99.81 & 99.71 & 99.83 & 99.67 \\
\hline Average & 99.81 & 99.95 & 99.93 & 99.92 & 99.90 & 99.82 & 99.85 & 99.87 \\
\hline SD & 0.25 & 0.12 & 0.08 & 0.19 & 0.11 & 0.15 & 0.27 & 0.15 \\
\hline RSD \% & 0.25 & 0.12 & 0.08 & 0.19 & 0.11 & 0.15 & 0.27 & 0.15 \\
\hline \multicolumn{9}{|c|}{ Intermediate precision within-laboratories variations $(\mathrm{n}=\mathbf{2 4})$} \\
\hline \multicolumn{5}{|c|}{ Laboratory-1 (Assay \%)-HPLC-1 } & \multicolumn{4}{|c|}{ Laboratory-2 (Assay \%)-HPLC-2 } \\
\hline Average & & \multicolumn{3}{|c|}{99.90} & \multicolumn{4}{|c|}{99.86} \\
\hline SD & \multicolumn{4}{|c|}{0.06} & \multicolumn{4}{|c|}{0.03} \\
\hline RSD \% & \multicolumn{4}{|c|}{0.06} & \multicolumn{4}{|c|}{0.03} \\
\hline \multicolumn{9}{|c|}{ Reproducibility between laboratories $(n=48)($ Assay \%) } \\
\hline Average & \multicolumn{8}{|c|}{99.88} \\
\hline SD & \multicolumn{8}{|c|}{0.02} \\
\hline RSD \% & \multicolumn{8}{|c|}{0.02} \\
\hline
\end{tabular}

TABLE 12: ROBUSTNESS DATA OF DAPAGLIFLOZIN

\begin{tabular}{cccccc}
\hline $\begin{array}{c}\text { Variations in method } \\
\text { parameters }\end{array}$ & $\begin{array}{c}\text { Retention Time } \\
(\text { min) }\end{array}$ & $\begin{array}{c}\text { Average peak } \\
\text { area* }\end{array}$ & RSD \% & \multicolumn{2}{c}{ System suitability parameters } \\
\cline { 3 - 6 } Buffer : Acetonitrile $(37: 63, \mathrm{v} / \mathrm{v})$ & 3.446 & 875485 & 0.05 & 2341 & Theoretical plates \\
Asymmetry \\
Buffer : Acetonitrile $(23: 77, \mathrm{v} / \mathrm{v})$ & 2.841 & 724885 & 0.11 & 2206 & 1.02 \\
$0.9 \mathrm{~mL} / \mathrm{min}$ Flow rate & 3.446 & 875715 & 0.05 & 2341 & 1.02 \\
$1.1 \mathrm{~mL} / \mathrm{min}$ Flow rate & 2.405 & 602098 & 0.08 & 2288 & 1.02 \\
\hline
\end{tabular}

* mean of six determinations

TABLE 13: ROBUSTNESS DATA OF SAXAGLIPTIN

\begin{tabular}{|c|c|c|c|c|c|}
\hline \multirow{2}{*}{$\begin{array}{l}\text { Variations in method } \\
\text { parameters }\end{array}$} & \multirow{2}{*}{$\begin{array}{c}\text { Retention Time } \\
(\text { min) }\end{array}$} & \multirow{2}{*}{$\begin{array}{c}\text { Average peak } \\
\text { area* }\end{array}$} & \multirow[t]{2}{*}{ RSD \% } & \multicolumn{2}{|c|}{ System suitability parameters } \\
\hline & & & & Theoretical plates & Asymmetry \\
\hline Buffer : Acetonitrile $(37: 63, \mathrm{v} / \mathrm{v})$ & 5.329 & 1066390 & 0.46 & 2890 & 1.01 \\
\hline Buffer : Acetonitrile $(23: 77, \mathrm{v} / \mathrm{v})$ & 4.180 & 870664 & 0.6 & 2724 & 1.03 \\
\hline $0.9 \mathrm{~mL} / \mathrm{min}$ Flow rate & 5.329 & 1063581 & 0.024 & 2990 & 1.04 \\
\hline $1.1 \mathrm{~mL} / \mathrm{min}$ Flow rate & 3.688 & 732120 & 0.221 & 2806 & 1.01 \\
\hline
\end{tabular}

CONCLUSION: The developed method is simple, precise, and accurate. Hence, the RP-HPLC method can be applied for the routine analysis of Dapagliflozin and Saxagliptin in bulk and pharmaceutical dosage forms.

ACKNOWLEDGEMENT: The authors wish to thank the management of Mewar University, Chittorgarh, Rajasthan, India, Pellets Pharma Limited, Sangareddy, Telangana, India and School of Pharmacy, Anurag Group of Institutions, Hyderabad, Telangana, India for providing the necessary equipment for research, constant encouragement, facilities, and support.

CONFLICTS OF INTEREST: The author declares that there is no conflict of interest to disclose.

\section{REFERENCES:}

1. Patel J and Patel P: RP- HPLC method development and validation for the estimation of diclofenac sodium, tramadol hydrochloride and chlorzoxazone from their combined tablet dosage form. Int Journal of Pharmacy and Pharmaceutical Sciences 2017; 6(7): 632-7.

2. Willard, Meritt, Dean and Settle: Instrumental Methods of Analysis. 7th edition, CBS Publishers and Distributors, New Delhi, 1986; 580-51.

3. Mastanamma SK, Chandini SK, Reehana SK and Saidulu P: Development and validation of stability indicating RPHPLC method for the simultaneous estimation of Sofosbuvir and Ledipasvir in bulk and their combined dosage form. Future Journal of Pharmaceutical Sciences 2018; 4(2): 116-23.

4. Swathi P, Dutt KR, Rao KNV and Raja MA: RP-HPLC method development and validation for estimation of Sofosbuvir in pure and tablet dosage form. Asian J Pharm Tech 2017; 7(3): 153-6.

5. Rani JS and Devanna N: Development and validation of RP-HPLC method for the simultaneous estimation of 
Sofosbuvir, Velpatasvir and Voxilaprevir in bulk and tablet dosage forms. Rasayan J. Chem 2018; 11(2): 452-9.

6. Tuwfeeq B: Development and validation of a new HPLC analytical method for the determination of diclofenac in tablets. Saudi Pharma 2019; 27(1): 66-70.

7. Zaman B, Siddique F and Hassan W: RP-HPLC method for simultaneous determination of Sofosbuvir and Ledipasvir in tablet dosage form and its application to invitro dissolution studies. Chromatographia 2016; 79(2324): 1605-13.

8. Saida SJ, Muniappan M, Kumar AM, Muralidaran K, Ramulu Y and Rao SV: Estimation of Sofosbuvir with validated Ultra High Performance Liquid Chromatographic (UHPLC) method in its bulk and formulations. Der Pharmacia Sinica 2017; 8(2): 10-5.

9. Lalitha KV, Reddy JR and Devanna N: Stability indicating RP-HPLC method development and validation for estimation of Sofosbuvir in pharmaceutical dosage form. The Pharma Innovation Journal 2018; 7(5): 656-62.

10. El-Kassem M, Hassouna $\mathrm{M}$, Abdelrahman $\mathrm{MM}$ and Mohamed MA: Assay and dissolution methods develop- ment and validation for simultaneous determination of Sofosbuvir and Ledipasvir by RP-HPLC method in tablet dosage forms. J Forensic Sci \& Criminal Inves 2017; 1(3): $1-11$.

11. Nagaraju T, Vardhan SVM, Kumar DR and Ramachandran D: A new RP-HPLC method for the simultaneous assay of Sofosbuvir and Ledipasvir in combined dosage form. International Journal of ChemTech Research 2017; 10(7): 761-8.

12. Hassouna MEM and Mohamed MA: UVspectrophotometric and stability indicating RP-HPLC methods for the determination of the Hepatitis C Virus inhibitor Sofosbuvir in tablet dosage form. Analytical Chemistry Letters 2018; 8(2): 217-29.

13. Sakinala P, Vahika H, Santhosh $K$ and Attinti S: Development and validation of stability indicating assay for simultaneous determination of pentaprazole, diclofenac, chloroxazone in pharmaceutical dosage form by using RP-HPLC. Int J Pharm Sci \& Res 2020; 11(4): 1757-67.

How to cite this article:

Mirzaee V, Jafarzadeh A, Tahmasebi A and Jalalpour S: Zingiber officinale effect on Helicobacter pylori infection in human; a systematic review. Int J Pharm Sci \& Res 2021; 12(1): 314-20. doi: 10.13040/IJPSR.0975-8232.12(1).314-20.

All $\odot 2013$ are reserved by the International Journal of Pharmaceutical Sciences and Research. This Journal licensed under a Creative Commons Attribution-NonCommercial-ShareAlike 3.0 Unported License.

This article can be downloaded to Android OS based mobile. Scan QR Code using Code/Bar Scanner from your mobile. (Scanners are available on Google Playstore) 